\title{
Seed banks of invasive Australian Acacia species in South Africa: Role in invasiveness and options for management
}

\author{
David M. Richardson ${ }^{\mathrm{a}, *}$, Robert L. Kluge ${ }^{\mathrm{b}}$ \\ ${ }^{a}$ Centre for Invasion Biology, Department of Botany and Zoology, Stellenbosch University, Private Bag XI, \\ Matieland 7602, South Africa \\ ${ }^{\mathrm{b}}$ ARC-Plant Protection Research Institute, Private Bag X6006, Hilton 3245, South Africa
}

Received 21 November 2007; received in revised form 29 February 2008; accepted 10 March 2008

\begin{abstract}
Despite impressive efforts at clearing stands of invasive Australian Acacia species in South Africa, insufficient attention has been given to understanding the role of seed banks in the invasiveness and long-term persistence of populations. We review information on seeds of these species, considering seed production, seed rain, and the dynamics of seeds in three layers: leaf litter, and upper and lower seed banks in the soil. Many factors affect the accumulation and susceptibility to destruction of seed banks and thus the opportunities for intervention to reduce seed numbers for each of these components. Reduction of seed banks is crucial for the overall success of the multi-million dollar management initiatives against these species. Classical biological control of buds, flower and young pods has reduced the seed production of many Australian acacias in South Africa. Fire can be applied to reduce seed numbers in the leaf litter and upper seed bank in some cases, although there are serious problems associated with high fire intensities in dense acacia stands. Other options, e.g. soil inversion and solarisation, exist to exercise limited reduction of seed numbers in some situations. There is little prospect of meaningful reduction of seed numbers in the lower seed bank. Preventing the accumulation of seed banks by limiting seed production through biological control is by far the most effective means, and in almost all cases the only practical means, of reducing seed numbers. This must be an integral part of management strategies. Several invasive Australian acacias are already under effective biological control, and further work to identify additional potential agents for all the currently invasive species and potentially invasive alien species is the top priority for improving the efficiency of management programmes.
\end{abstract}

(C) 2008 Rübel Foundation, ETH Zürich. Published by Elsevier GmbH. All rights reserved.

Keywords: Biological control; Biological invasions; Exotic species; Invasive alien species; Fabaceae

\section{Introduction}

Sustainable management of invasive plants demands the integration of biological, chemical and mechanical control options, along with various forms of cultural control including, for example, grazing management,

\footnotetext{
*Corresponding author.

E-mail address: rich@sun.ac.za (D.M. Richardson).
}

prescribed burning, and restoration programmes. The success of many plant species as invaders is increased by their capacity to maintain persistent stores of seeds in the soil. The resilience of persistent seed banks is a major obstacle to effective and sustainable management of invasive plants in many parts of the world. For invasive species with durable seed banks, measures that deal effectively only with mature plants are very unlikely to be sufficient to drive populations below tolerable density 
thresholds. They provide, at best, temporary solutions to the problem. Some notable examples of major invasive plant species whose management is bedevilled by persistent seed banks are Bromus tectorum, Centaurea solsticialis, Heracleum mantegazzianum, Lythrum salicaria, Miconia calvescens, Mimosa pigra, Rubus alceifolius, and Ulex europaeus. Soil-stored seed banks of invasive alien legumes are a crucial part of their recipe for success as invaders and are the bane of managers in many parts of the world (Paynter et al., 2003). In South Africa, numerous trees and shrubs of the family Fabaceae have invaded large areas of natural and semi-natural vegetation (Richardson et al., 1997; Nel et al., 2004) where they cause substantial impacts (Richardson and Van Wilgen, 2004) and are the targets of expensive control operations (Marais et al., 2004). This paper reviews the dynamics of the seed banks of invasive Australian Acacia species in South Africa with special reference to the role of seed banks in invasiveness and persistence and options for managing these species by manipulating the seed banks. Since these species are widely planted as aliens in many parts of the world, and are invasive in many of these areas (Richardson et al., 2004), these findings should be of interest beyond South Africa.

\section{Australian Acacia species in South Africa}

Many Australian Acacia species, including A. cyclops, A. dealbata, A. decurrens, A. longifolia, A. mearnsii, A. melanoxylon, $A$. pycnantha and $A$. saligna, were introduced to South Africa in the middle of the 19th century for commercial, cultural and horticultural purposes (Stirton, 1978; Richardson et al., 2003). Nomenclature for Acacia species discussed in this paper follows Maslin (2001). Since their introduction, several species have invaded conservation areas, agricultural land, watercourses and catchments (Stirton, 1978; Richardson et al., 1997). Twelve Australian Acacia species were listed as either "major invaders" (nine species) or "emerging invaders" (three species) in an objective classification of invasive alien plant species in South Africa to prioritise species and areas for management action (Table 1 in Nel et al., 2004). Most of these species are invasive in riparian habitats as well as terrestrial ecosystems. Of the major invaders, only $A$. dealbata was classified as predominantly invasive in riparian habitats, while $A$. pycnantha was classified as a "landscape" invader (invasive mainly away from riparian zones) (Rouget et al., 2004). Australian acacias are important invasive species in all of South Africa's terrestrial biomes (Richardson et al., 1997), but the fynbos biome has more highly invasive species and has suffered the greatest impacts from these species
(Richardson et al., 1992). The ranges of all the species listed as major invaders are at least partly attributable to their dissemination by humans (Richardson et al., 2003; Wilson et al., 2007). Natural disturbances such as fire and coastal dune movements and a range of anthropogenic disturbances are crucial for regeneration and proliferation (e.g. Richardson et al., 1992 for fynbos). Interactions with resident biota (native and introduced) have important facilitative (notably seed dispersal and mycorrhizas) and inhibitive (notably seed predation) roles in the dynamics of these species. All species have durable soil-stored seeds and are dispersed unintentionally over wide distances and in large numbers through soil movement by humans, for example in topsoil, gravel for roads, mud on cars, and with horticultural stock (personal observation). Passive dispersal in water along rivers has been crucial for the rapid invasion in many parts of South Africa. Some species are virtually confined to habitats along rivers whereas others, notably A. mearnsii, spread into terrestrial habitats in parts of their range following dispersal along rivers. The combined effects of rivers as agents of dispersal and disturbance provides a crucial and complex template that drives invasions and complicates management of these species over much of their range in South Africa (Holmes et al., 2005; Foxcroft et al., 2007; Richardson et al., 2007). Information collated from many sources in this paper underscores the crucial role of large seed banks in invasiveness and persistence of Australia acacias and the need to manage seeds to achieve sustainable control.

The main impacts that the invasive acacias have in natural and semi-natural ecosystems in South Africa include the following: (i) in fynbos they change plant community structure and increase flammability through increased fuel loads (Van Wilgen and Richardson, 1985); (ii) in fynbos they increase soil erosion due to water repellancy induced by very intense fires in dense stands (Euston-Brown et al., 2002); (iii) especially in fynbos they change soil chemistry (Stock et al., 1995; Yelenik et al., 2004, 2007) which transforms ecosystems leading to, among other things, increased invasion by alien grasses (Richardson et al., 2000c); (iv) especially in fynbos dense stands lead to reduced native species diversity (Richardson et al., 1989); (iv) especially in fynbos dense stands reduce water production in catchments (Le Maitre et al., 1996); (v) in riparian habitats in all biomes, dense stands transform native communities with marked alteration of ecosystem functioning (Holmes et al., 2005); (vi) in all biomes dense stands lessen the aesthetic, recreational and scientific value of plant communities (Kruger, 1979), and (vii) in coastal ecosystems dense stands stabilise naturally mobile sand dunes, altering coastal sediment movement and leading to extensive beach erosion (Lubke, 1985). Another widely perceived problem associated with invasive 
acacias is that they provide cover for thieves and criminals, mainly in poorer areas (de Neergaard et al., 2005). The scale of invasions is immense. For example, dense stands of acacias, mainly $A$. cyclops and A. saligna, form impenetrable stands over thousands of hectares in lowlands of the fynbos biome (Rouget et al., 2003). In both areas of the fynbos biome where invasive plants have been mapped most accurately (the Cape Peninsula and the Agulhas Plain) A. cyclops is the most widespread invader (Richardson et al., 1996; Rouget and Richardson, 2003) and has considerable potential for further spread (Higgins et al., 2000; Rouget and Richardson, 2003). Many South African rivers are fringed with dense stands of Australian acacias, particularly A. mearnsii (Holmes et al., 2005).

Inherent characteristics of the Australian acacias, including their rapid growth rates (Witkowski, 1991) and copious seed production (Milton, 1980b), together with the absence of natural enemies (Milton, 1980b), have given them a competitive advantage over native plant species. A vital factor in their success is the accumulation of very large seed banks in the soil (Dean et al., 1986) (Fig. 1). The extreme persistence of the seeds ( $>50$ years Holmes, 1989a; longer than any native plant species; Holmes and Newton, 2004) is due to physical dormancy (Baskin and Baskin, 1998; Thompson et al., 2003) caused by the impermeability of their seed coats (Rolston, 1978). Non-dormant seeds may temporarily contribute to the seed bank while conditions for germination are sub-optimal. Several of the Australian acacias (notably $A$. mearnsii, $A$. melanoxylon and $A$. saligna) resprout vigorously from roots after fire or mechanical clearing, further complicating control (Van Wilgen et al., 1992).
About 1 million hectares of initial clearance, including acacias, was achieved during the first 7 years of the government-sponsored Working for Water (WfW) Programme of the Department of Water Affairs and Forestry (WfW Annual Reports; www.dwaf.gov.za/ $\mathrm{wfw} /$ ). The estimated cost to clear the alien plant invasions in South Africa is around US\$ 1.2 billion, or US\$ 60 million per year for 20 years (Van Wilgen et al., 2001). Most attention in the Working for Water Programme has been given to the removal of aboveground material using chemical and mechanical means (Van Wilgen et al., 1992). The results are generally impressive. The clearing programme is complemented by biological control, focusing mainly on suppressing the reproductive potential of the species (Dennill et al., 1999; Zimmermann et al., 2004), and limited restoration initiatives (Holmes and Richardson, 1999; Holmes et al., 2005, 2008). Although the importance of seed banks in control has long been recognised (Milton and Hall, 1981; Holmes et al., 1987a), little attention has been given to addressing the reduction of seed banks as part of the overall control strategy of the Working for Water Programme as was done, for example, in the programme against $L$. salicaria in the USA (Welling and Becker, 1990). Furthermore, there is no explicit recognition in policy documents regarding the implications of the failure to deal with the persistent seed banks of invasive acacias for the long-term success of this multi-million dollar control programme. The effectiveness of followup control (Campbell, 2000) could be seriously compromised by the unpredictable and sporadic, lowdensity recruitment and reinvasion from seed banks over vast areas. If there were to be any reduction or interruption of the current clearing programme,

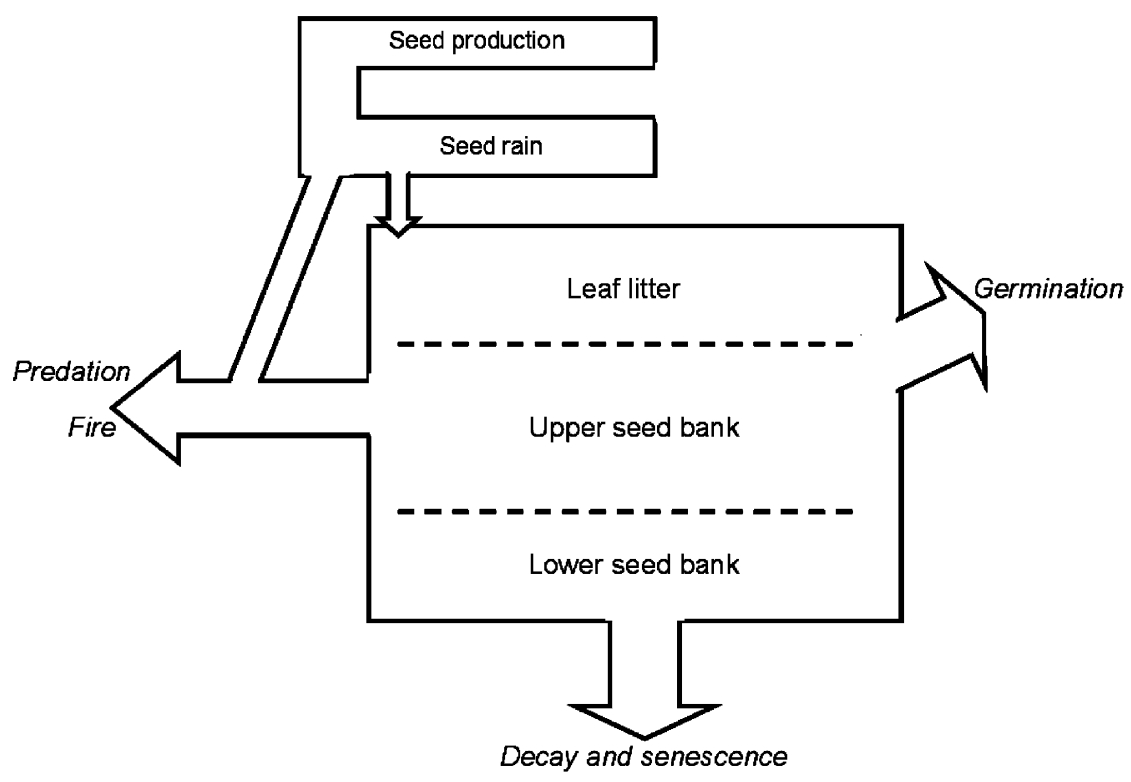

Fig. 1. Conceptualisation of the dynamics of seeds in seed banks (modified from Harper, 1977). 
re-invasion from seed banks could jeopardize all the resources invested until now.

\section{The role of seed banks in the ecology of Australian acacias in South Africa}

We recognise five components for possible intervention for the management of Australian Acacia seed banks: seed production, seed rain, leaf litter, upper seed bank and lower seed bank (Fig. 1, Table 1).

\section{Seed production}

This constitutes the potential seed rain (Table 1). Three stages of the potential seed rain production are recognised: reproductive buds, flowers and the immature pods. Fruiting efficiency (number of pods per

Table 1. A synthesis of information on Australian Acacia seed banks in South Africa prior to biological control, showing five components and summarizing loss and movement factors

\begin{tabular}{|c|c|c|c|}
\hline Position & Components & Loss factors & Movement factors \\
\hline $\begin{array}{l}\text { Above } \\
\text { ground } \\
\text { - The tree } \\
\text { canopy }\end{array}$ & $\begin{array}{l}\text { Seed production } \\
\text { - Reproductive buds } \\
\text { and flowers and } \\
\text { immature pods }\end{array}$ & $\begin{array}{l}\text { - Natural abortion of buds and flowers }(99 \%) \\
\text { and immature pods }(95 \%) \\
\text { - Predation of immature pods by a tortricid } \\
(28 \%) \\
\text { - Fire }\end{array}$ & Not applicable \\
\hline & $\begin{array}{l}\text { Seed rain } \\
\text { - Mature seeds } \\
\begin{array}{l}15,000 \text { seeds } \mathrm{m}^{-2} \\
\text { per annum } \\
99 \% \text { viable } \\
2-8 \% \text { seeds can } \\
\text { germinate } \\
\text { immediately }\end{array}\end{array}$ & $\begin{array}{l}\text { - Predation by alydids }(90 \%) \text { of seeds of } \\
\text { ornithochorous species retained in the canopy } \\
\text { for a time } \\
\text { - Fire }\end{array}$ & $\begin{array}{l}\text { - Birds disperse seeds of ornithochorous } \\
\text { species }\end{array}$ \\
\hline
\end{tabular}

On the
ground

- The

interface
Litter layer

- Unconsolidated litter
- Fire kills most seeds

- Predation by rodents $(1 \%)$

- Predation by alydids

- Argentine ants (Linepithema humile) remove elaiosomes of myrmecochorous species exposing them to fire
- Indigenous ants possibly move $90 \%$ and $40 \%$ of myrmecochorous and ornithochorous species, respectively

- Birds

- Burrowing organisms cause movement of seeds downwards to the upper seed bank

- Water

- Burrowing organisms cause upward and downward movement of seeds
Below ground

- The actual

seed

bank

Upper seed bank, top $10 \mathrm{~cm}$

\footnotetext{
- $<80 \%$ of seeds in seed bank

- 48,000 seeds $\mathrm{m}^{-2}$

- $85 \%$ viable

- $95 \%$ seeds subject to physical dormancy
}

Lower seed bank, $10-80 \mathrm{~cm}$

- Limited decay

- Gradual senescence
- Burrowing organisms cause upward and downward movement of seeds

- $>20 \%$ of seeds

- $35 \mathrm{~cm}$ in sandy soils

- Longevity of 50 years or more 
inflorescence) is typically low; less than $1 \%$ of the flowers of $A$. cyclops, A. longifolia, A. podalyriifolia, $A$. melanoxylon and $A$. saligna produce mature pods (Milton and Hall, 1981); this is similar to that of an indigenous acacia, A. karroo (Milton and Hall, 1981). Natural loss of immature pods is also high; for example, for $A$. cyclops it is $85-95 \%$ (Milton and Hall, 1981). In South Africa, there have been no reports of mortality of flower buds and flowers of any of the Australian acacias due to damage caused by indigenous organisms. Donnelly and Stewart (1990) reported a tortricid moth larva destroying $28 \%$ of the immature pods of A. cyclops.

\section{The seed rain}

This is the realised seed production (Table 1). The annual recorded seed rain of Australian acacias ranges from ca. 2000 seeds $\mathrm{m}^{-2}$ for A. cyclops (Milton and Hall, 1981 ) to 11,500 seeds $^{-2}$ for $A$. longifolia (Pieterse, 1987 ) as measured on the ground (Table 2). About $2-8 \%$ of Australian acacia seeds in the seed rain can germinate immediately (Milton and Hall, 1981). The vast majority of the seeds are added to the seed bank where they remain dormant until the testa is damaged or weathered sufficiently to be permeable to water and germinate (Milton and Hall, 1981).

The seed rain of ornithochorous (= bird-dispersed) species such as A. cyclops and A. melanoxylon is reduced by local bird species (Glyphis et al., 1981; Geldenhuys, 1986), while being retained temporarily in the canopy for dispersal by birds. Fraser (1990) reported that $A$. cyclops seeds occurred in $95 \%$ of pellets regurgitated by redwinged starlings (Oychognathus morio morio) at a roost on the Cape Peninsula over 1 year. Pied starlings (Spreo bicolor) also consume A. cyclops seeds (Török, 1999). In some areas, large amounts of seeds are consumed by barn swallows (Hirundo rustica; Underhill and Hofmeyr, 2007). Baboons also feed on A. cyclops pods and seeds (P.M. Holmes, personal communication). Seeds consumed by birds are scarified which reduces dormancy (Glyphis et al., 1981), i.e. they germinate readily and are less likely to be incorporated into the seed bank. A maximum of $36 \%$ of $A$. cyclops seeds passed by birds germinated after 6 weeks (Milton and Hall, 1981). In the south-western part of the Western Cape province (hereafter south-western Cape), seeds in the canopy are also fed on by indigenous alydids which destroy or damage up to $84 \%$ of the $A$. cyclops seed; the viability of damaged seed in the seed bank is also reduced (Holmes et al., 1987b; Holmes and Rebelo, 1988). Alydid damage appears to occur widely among Australian acacias, and can destroy up to $100 \%$ of seeds, e.g. in $A$. melanoxylon and $A$. implexa (Pieterse, 1998). Although the potential for the reduction of the seed rain is high, it has been neither sufficiently high nor consistent enough historically to prevent these species from becoming invasive.

Table 2. Maximum recorded values of seed rain and seed banks of some Australian Acacia species in South Africa

\begin{tabular}{|c|c|c|c|c|c|c|c|}
\hline \multirow{2}{*}{$\begin{array}{l}\text { Acacia } \\
\text { species }\end{array}$} & \multicolumn{3}{|l|}{ Seed rain } & \multicolumn{3}{|l|}{ Seed bank } & \multirow{2}{*}{$\begin{array}{l}\text { Estimated accumulation } \\
\text { time for mean seed bank } \\
\text { (years) }^{\text {b }}\end{array}$} \\
\hline & $\begin{array}{l}\text { Annual seed } \\
\text { rain } \mathrm{m}^{-2 \mathrm{a}}\end{array}$ & $\%$ Viability & $\%$ Dormancy & $\begin{array}{l}\text { Seed } \\
\text { density } \mathrm{m}^{-2}\end{array}$ & $\%$ Viability & $\begin{array}{l}\% \\
\text { Dormancy }\end{array}$ & \\
\hline A. baileyana & - & - & $\begin{array}{l}93-97 \\
\text { (Pieterse, } \\
1987)\end{array}$ & - & - & - & - \\
\hline A. cyclops & $\begin{array}{l}1977 \text { (Milton } \\
\text { and Hall, } \\
\text { 1981) }\end{array}$ & $\begin{array}{l}100 \text { (Jeffery } \\
\text { et al., 1988) }\end{array}$ & $\begin{array}{l}80-98 \\
\text { (Holmes, } \\
1988)\end{array}$ & $\begin{array}{l}5100 \text { (Holmes } \\
\text { et al., 1987a) }\end{array}$ & $\begin{array}{l}99 \text { (Holmes, } \\
1989 b)\end{array}$ & $\begin{array}{l}98 \text { (Holmes, } \\
1989 b)\end{array}$ & 11 \\
\hline A. longifolia & $\begin{array}{l}11,500 \\
\text { (Pieterse, } \\
1987)\end{array}$ & - & $\begin{array}{l}96 \text { (Pieterse } \\
\text { and Cairns, } \\
1986)\end{array}$ & $\begin{array}{l}\text { 34,000 (Pieterse } \\
\text { 1987) }\end{array}$ & $\begin{array}{l}97 \text { (Milton } \\
\text { and Hall, } \\
\text { 1981) }\end{array}$ & $\begin{array}{l}98 \text { (Milton } \\
\text { and Hall, } \\
\text { 1981) }\end{array}$ & \\
\hline A. mearnsii & - & - & - & $\begin{array}{l}5314 \text { (Pieterse, } \\
1997)\end{array}$ & $\begin{array}{l}83 \text { (Milton } \\
\text { and Hall, } \\
\text { 1981) }\end{array}$ & - & 8 \\
\hline $\begin{array}{l}\text { A. } \\
\text { melanoxylon }\end{array}$ & $\begin{array}{l}3200 \text { (Milton } \\
\text { and Hall, } \\
\text { 1981) }\end{array}$ & - & - & $\begin{array}{l}\text { 48,739 (Milton } \\
\text { and Hall, 1981) }\end{array}$ & $\begin{array}{l}70 \text { (Milton } \\
\text { and Hall, } \\
\text { 1981) }\end{array}$ & - & 25 \\
\hline A. saligna & $\begin{array}{l}5443 \text { (Milton } \\
\text { and Hall, } \\
1981 \text { ) }\end{array}$ & $\begin{array}{l}98 \text { (Jeffery } \\
\text { et al., 1988) }\end{array}$ & $\begin{array}{l}97 \text { (Jeffery et } \\
\text { al., 1988) }\end{array}$ & $\begin{array}{l}\text { 46,000 (Holmes } \\
\text { et al., 1987a) }\end{array}$ & $\begin{array}{l}\text { 96-97 } \\
\text { (Holmes, } \\
1988)\end{array}$ & $\begin{array}{l}96 \text { (Milton } \\
\text { and Hall, } \\
\text { 1981) }\end{array}$ & 8 \\
\hline
\end{tabular}




\section{The leaf litter}

This is the interface between the seed rain from the canopy and the soil seed bank; it consists of the unconsolidated litter (Milton and Hall, 1981). There are four main loss factors: fire, alydids, ants and rodents (Table 1). Granivorous birds such as Cape spurfowl (Francolinus capensis; P.M. Holmes, personal communication), helmeted guineafowl (Numida meleagris; Duckworth and Richardson, 1988) and black korhaans (Afrotis afra; Knight and Macdonald, 1991) consume seed from the litter layer. Fire, the most important mortality factor, is discussed under "the upper seed bank." Alydids may feed on exposed seeds in the leaf litter (S. Neser, personal communication) but this loss has not been quantified.

In $A$. cyclops and $A$. saligna there may be a relative "loss" to annual seed rain of $50 \%$ and $80-95 \%$, respectively, due to ants, rodents and rotting (Holmes, $1990 \mathrm{a}, \mathrm{b})$. The seeds of myrmecochorous species (i.e. seeds with elaiosomes), such as $A$. longifolia, $A$. mearnsii and $A$. saligna, are removed by indigenous ants (Midgley and Bond, 1995; French and Major, 2001). Ants take seeds into their nests, at depths of $4-7 \mathrm{~cm}$ below the soil surface (Bond and Slingsby, 1983, 1984), where they are effectively incorporated into the seed bank, making them less likely to succumb to fire. The seeds of ornithochorous species (i.e. seeds with arils), such as $A$. cyclops and A. melanoxylon, are also removed by ants but to a lesser degree (Holmes, 1990a, b). In a trial using trays and exclusion techniques, ants (mainly Anoplolepis and Pheidole species) removed 94\% and $36 \%$ of the $A$. saligna and $A$. cyclops seeds, respectively, after 7 days. In a similar trial, involving six species of ants (Tetramorium, Ocymyrmex and Linepithema species), over $90 \%$ and $10 \%$ of seeds of $A$. mearnsii and A. melanoxylon, respectively, were removed (Pieterse, 1997). Therefore, just as ants are important for maintaining seed banks of indigenous Proteaceae (Bond and Slingsby, 1984), they might play a critical role in accumulating seed banks of Australian acacias in South Africa (Holmes, 1990c; Richardson et al., 2000a). The alien Argentine ant (Linepithema humile) which, unlike indigenous ants, removes the elaiosomes from the seeds without burying them (Bond and Slingsby, 1984), prevents seeds of species with elaiosomes such as A. longifolia and A. mearnsii from being added to the seed bank, thus fortuitously making them more vulnerable to fires. Apart from myrmecochory, movement of seed from the litter layer into the seed bank appears to be very slow and was measured to be only $3 \%$ after 1 year for seed without elaiosomes in sand plain fynbos (Holmes, 1990c). No information is available on seed movement patterns in dune systems.

In the aforementioned trials of Holmes (1990a, b), rodents, mainly the striped field mouse (Rhabdomys pumilo), were slower to take seeds than the ants: $31 \%$ and $35 \%$ after 7 days for A. saligna and A. cyclops, respectively. The striped field mouse normally takes about $1 \%$ of the annual seed production of standing Australian acacia thickets (Milton and Hall, 1981). Resident rodent populations in fynbos could potentially consume the entire acacia seed crop from outliers and low-density stands were it not for the presence of ants that rapidly remove seeds to their nests (Holmes, 1990a, b).

\section{The upper seed bank}

This is where conditions are most likely to be favourable for non-dormant seeds to germinate, and consequently where most germination occurs. Based on studies of the seed banks of $A$. cyclops and A. saligna (Holmes, 1990c) and A. mearnsii and A. melanoxylon (Pieterse, 1997), the upper seed bank for Australian Acacia species (Table 1) occurs in approximately the top $10 \mathrm{~cm}$ of the soil.

Seed bank densities of Australian acacias in South Africa range from ca. 2000 seeds $\mathrm{m}^{-2}$ for $A$. cyclops to 48,000 seeds $\mathrm{m}^{-2}$ for $A$. melanoxylon (Table 2). The size of the seed bank is determined mainly by (1) the size of the annual seed rain (Table 2), which is inherently related to the physical sizes of seeds or the plant's energy investment per seed; (2) the age of the stand. Although 2year-old $A$. saligna saplings can set seed, large crops of seeds are not produced until after 5 years or more in the case of A. melanoxylon. The rate of seed accumulation appears to increase until the trees are about 30 years old and then remains stable (Milton and Hall, 1981); (3) stand density or canopy cover (Holmes, 1990a); (4) distance from canopy. Seed density in the seed bank is highest under the tree canopy and decreases sharply with distance away from it (Milton and Hall, 1981).

Most of the seed in the seed banks of Australian acacias in the south-western Cape are found in the top $8 \mathrm{~cm}$ (Milton and Hall, 1981). Campbell et al. (1999) found $46 \%$ of $A$. dealbata seeds in the top $6 \mathrm{~cm}$, and for A. longifolia $58 \%$ of the seed occurred in the top $3 \mathrm{~cm}$ (Pieterse and Cairns, 1986). The vertical distribution of seeds in the soil is affected by soil and habitat conditions. Consequently, in deep lowland sands, particularly where there is high fossorial mammal activity, seeds are likely to be distributed to a greater depth than in shallow sandstone-derived soils (Holmes, 1990c). The horizontal and vertical distribution of seeds in the seed bank in the soil may vary from even to clumped. The latter is due to the accumulation of seeds in ant nests (Milton and Hall, 1981) and other processes in the soil that tend to cause aggregation of seeds (see below). 
Seeds from Australian acacia seed banks are generally $85 \%$ viable (Milton, 1980a) and may remain dormant for 50 years or more (Holmes, 1989a). The percentage of non-viable seed recovered from the soil is low: A. cyclops $(5.2 \%)$, A. longifolia $(1.5 \%)$, A. melanoxylon $(0 \%)$ and A. saligna (1.0\%) (Milton and Hall, 1981). Viability of older $A$. mearnsii seeds was just as high as the younger seeds, but the seedlings appeared less vigorous (Pieterse and Boucher, 1997). However, at least $90 \%$ of the seeds in the seed bank will not germinate because of physical dormancy. Milton and Hall (1981) reported 90.8\% and $93.4 \%$ and Holmes (1988) $91.2 \%$ and $89.6 \%$, respectively, for dormancy levels in A. cyclops and $A$. saligna. The oldest $A$. cyclops seeds (from at least $25 \mathrm{~cm}$ below the soil surface) germinated most readily after treatment and the youngest (from down to $8 \mathrm{~cm}$ ) most tardily (Milton and Hall, 1981). In burnt and unburnt plots, $3.7 \%$ and $0.01 \%$ of $A$. longifolia seeds, respectively, germinated (Pieterse and Cairns, 1986). The soil-stored seeds of Australian acacias showed similar levels of dormancy and viability as fresh material (Milton and Hall, 1981). Site differences in germinability and viability were also found with $A$. cyclops, which might be attributable to differential exposure to the elements or alydid feeding (Milton and Hall, 1981).

Australian acacia seeds can be divided into two groups of physical dormancy based on the structure and degree of permeability of the testa (Pieterse, 1997) and the related dispersal strategies (Davidson and Morton, 1984; O'Dowd and Gill, 1986) (Table 3). Type A seeds are fire adapted with an elaiosome that predisposes it to vertical dispersal into the soil by ants, i.e. myrmecochory. The water impermeability of the seed coat of this group persists, and it has a single high temperature requirement to break the dormancy (e.g., A. saligna; Jeffery et al., 1988). The heat pulse acts on the weakest area of the testa, the lens (Manning and Van Staden, 1987). In contrast, Type B seeds are adapted for ornithochory with a prominent brightly coloured aril, and a seed coat that more readily loses water impermeability than Type A seeds (Holmes and Moll, 1990). Dormancy, for example of A. melanoxylon, is more efficiently broken by acid scarification (Pieterse, 1997); i.e., by digestive processes in animals (birds) and by aging (Milton and Hall, 1981). For example, Jeffery et al. (1988) concluded that $A$. cyclops seed has a cyclical less severe heat requirement to break dormancy, such as may occur on exposed soil surfaces during summer. The Type A group has potentially low germination and decay rates and high longevity in the absence of fires (Holmes and Moll, 1990). Type A seeds that are taken into ant nests are probably better adapted at germinating from greater depths than bird-dispersed (Type B) species which are deposited on the soil surface (Pieterse, 1997).
Table 3. A classification of Australian Acacia seeds and seed banks based on characteristics of the aril according to O'Dowd and Gill (1986)

\begin{tabular}{|c|c|c|}
\hline Acacia & Type A & Type B \\
\hline & $\begin{array}{l}\text { Seed characteristics } \\
\text { - Water } \\
\text { impermeability } \\
\text { of testa persists } \\
\text { - Dormancy } \\
\text { primarily } \\
\text { broken by heat } \\
\text { pulse, e.g. fire } \\
\text { - Aril small and } \\
\text { colourless } \\
\text { - Adapted for } \\
\text { myrmechocory, } \\
\text { i.e. elaiosome } \\
\text { - Adapted for fire } \\
\text { prone habitats }\end{array}$ & $\begin{array}{l}\text { - Water } \\
\text { permeability of } \\
\text { testa does not } \\
\text { persist } \\
\text { - Dormancy } \\
\text { primarily broken } \\
\text { by scarification } \\
\text { e.g. digestive } \\
\text { processes in birds } \\
\text { - Aril prominent } \\
\text { and brightly } \\
\text { coloured } \\
\text { - Adapted for } \\
\text { ornithochocory } \\
\text { - From relatively } \\
\text { fire-free habitats }\end{array}$ \\
\hline & $\begin{array}{l}\text { Seed bank character } \\
\text { - Type IV model } \\
\text { - persistent } \\
\text { - Small } \\
\text { proportion of } \\
\text { the seeds } \\
\text { germinate or } \\
\text { decay within the } \\
\text { first } 3 \text { months } \\
\text { and the majority } \\
\text { persist } \\
\text { thereafter } \\
\text { - Slow turnover } \\
\text { - Rapid } \\
\text { accumulation } \\
\text { b }\end{array}$ & $\begin{array}{l}\text { - Type III model }{ }^{\mathrm{a}}- \\
\text { intermediate } \\
\text { between transient } \\
\text { and persistent type } \\
\text { - Majority of the } \\
\text { seeds germinate or } \\
\text { decay over the first } \\
\text { twelve months, } \\
\text { after which only } \\
\text { 20-40\% will } \\
\text { persist } \\
\text { - Rapid turnover } \\
\text { - Gradual } \\
\text { accumulation } \\
\text { b }\end{array}$ \\
\hline
\end{tabular}

\begin{tabular}{|c|c|}
\hline A. baileyana & $\mathrm{X}$ \\
\hline A. cyclops & \\
\hline A. dealbata & $\mathrm{X}$ \\
\hline A. decurrens & $\mathrm{X}$ \\
\hline A. elata & $\mathrm{X}$ \\
\hline A. implexa & $\mathrm{X}$ \\
\hline A. longifolia & $\mathrm{X}$ \\
\hline A. mearnsii & $\mathrm{X}$ \\
\hline A. melanoxylon & \\
\hline A. paradoxa & $\mathrm{X}$ ? \\
\hline A. podalyriifolia & $\mathrm{X}$ \\
\hline A. pycnantha & $\mathrm{X}$ \\
\hline
\end{tabular}

${ }^{\mathrm{a}}$ Thompson and Grime (1979).

${ }^{\mathrm{b}}$ Holmes and Moll (1990).

Type A seed banks conform to the Type IV persistent seed bank model of Thompson and Grime (1979) which confers potential for regeneration in unpredictable, disturbed habitats such as those adapted for fire. For example in A. saligna, germination and decay of small proportions of the seeds occurs within the first 3 
months, with little thereafter. This suggests that the persisting population is relatively more hard-seeded and resistant to decay. In the Type B group, germination and decay of a large proportion of the seeds occurs during the first year with a small proportion persisting thereafter. This conforms best to the Type III model, which has characteristics intermediate between those of transient (Type I) and persistent type (Type IV) seed banks (Thompson and Grime, 1979). For example, in $A$. cyclops the majority of the seeds germinate or decay throughout the first 12 months, after which only $20-40 \%$ of the population persist (Milton and Hall, 1981; Holmes and Moll, 1990). The degree of hardseededness of a species may vary between sites as Gill (1985) found in Australia, and between cohorts (Holmes and Moll, 1990). From available evidence, the Australian acacias in South Africa can provisionally be classified in the two groups as shown in Table 3.

The three most important loss factors affecting the seeds in the upper seed bank are fire-related mortality, germination (Milton and Hall, 1981) and decay (Holmes, 1989a). Holmes and Moll (1990) reported that small mammals destroyed up to $50 \%$ in the top $5 \mathrm{~cm}$ in a burial trial, when seeds were buried in uninvaded fynbos vegetation, but this may have been an artefact of the trial. However, indigenous rodents may be less active in dense acacia stands (Holmes, 1990a). Fire has the greatest potential to instantly and dramatically reduce the seed banks. Fire killed $90 \%$ of $A$. longifolia seeds in the seed bank (Pieterse and Cairns, 1988) and all A. cyclops seeds in the upper $30 \mathrm{~mm}$ of soil (Holmes, $1989 b)$. In a burial trial with a moderate to intense fire, all $A$. longifolia seeds at $1 \mathrm{~cm}$ were destroyed, $93 \%$ of the seeds at $2 \mathrm{~cm}$ were viable and germinated and those at $3 \mathrm{~cm}$ remained dormant (Pieterse and Cairns, 1986).

In the absence of fire, germination may account for about $9 \%$ and $10 \%$ of the loss from $A$. cyclops and A. saligna seed banks, respectively (Holmes and Moll, 1990). Acacia mearnsii seedlings germinated from $1.4 \mathrm{~cm}$ up to $2.7 \mathrm{~cm}$ depth with a maximum of $6.2 \mathrm{~cm}$ (Pieterse and Boucher, 1997), but in a burial trial most $A$. saligna and $A$. cyclops seedlings emerged from 10 and $5 \mathrm{~cm}$, respectively, despite the latter's potential to emerge from greater depths (Holmes and Moll, 1990). Successful emergence of seedlings germinating below $10 \mathrm{~cm}$ is limited by lack of seed energy reserves (Milton and Hall, 1981). Generally, the depth from which seeds can germinate successfully is positively correlated with size (Hendrix and Trapp, 1992).

Seed bank decay rates due to germination, pathogens, rotting, physiological aging for A. cyclops (Type B) averaged $96.6 \%$ and $72.1 \%$ compared to $45.4 \%$ and $14.9 \%$ for $A$. saligna (Type A) for $0-1$ and $1-2$ years, respectively (Holmes, 1989a). Holmes (1989a) concluded that decay rates for $A$. cyclops and $A$. saligna in the south-western Cape did not fit the constant death model of (Roberts and Feast, 1972; see also Harper, 1977) derived largely for agricultural weed seeds. Acacia seeds that survived the first year in the seed bank had a greater chance of surviving the second and succeeding years. Rotting A. cyclops seeds recovered from the seed bank were attributed to feeding by alydids (Holmes, 1988). Loss of viability through aging is considered to be much reduced in seeds with physical dormancy (Holmes, 1989a) and, consequently, is unlikely to be important in the decay of seed of Australian acacia seed banks. There are no indisputable data on the longevity of acacia seeds, but in Australia acacia seedlings appeared when climax eucalyptus forest, 200-400 years old, was destroyed by fire (Milton and Hall, 1981). In KwaZuluNatal, regeneration densities of $A$. mearnsii of 5000 and 1482 plants $\mathrm{ha}^{-1}$ were recorded on sites of former wattle plantations after 20 and 44 years, respectively, of maize cultivation (Milton and Hall, 1981).

Apart from one study by Holmes (1990c), little is known about movement of the acacia seeds within the soil seed bank. In a seed burial trial in sandplain fynbos vegetation, burrowing rodents were important agents for both upward and downward movement of the $A$. saligna seed (Holmes, 1990c). In rodent-disturbed sites, more seeds moved up than down, and in undisturbed sites upward movement was negligible and downward movement of seeds was greater (Holmes, 1990c), which probably resulted from seeds falling down vertebrate burrows, holes left by decaying roots or drying fractures, facilitated by the action of percolating rain water (Harper, 1977). In the south-western Cape, the activities of burrowing animals, such as the dune mole (Bathyergus sullius), and also snakes, frogs and insects have been implicated in seed burial (Milton and Hall, 1981). Where burrowing animals are absent, the seeds tend to be concentrated closer to the soil surface (Holmes, 1990c).

\section{The lower seed bank}

Germination of seeds stored below approximately $10 \mathrm{~cm}$ is less likely, although seedling emergence may occur from as deep as $15 \mathrm{~cm}$ (Holmes and Moll, 1990). In this zone, seeds are better insulated from soil surface temperature fluctuations and may remain in a state of physical dormancy for longer than those at the soil surface. Acacia seeds may occur up to a depth of $35 \mathrm{~cm}$ (Holmes, 1990c), particularly in loose sandy soil (Milton and Hall, 1981) and even up to $80 \mathrm{~cm}$ in riparian habitats (Esler and Boucher, 2004). Below $8 \mathrm{~cm}$ the density of seeds in the Australian acacia seed bank may decrease sharply (Milton and Hall, 1981), but this may be site specific with a greater degree of burial in sites where fossorial mammals are active (Holmes, 1990c) and in riparian areas (Esler and Boucher, 2004). The 
dominant seed attrition factors in this zone are decay, germination and death owing to unsuccessful emergence (Fig. 1).

The migration of seeds to and from the lower seed bank is driven by the factors mentioned above. Seeds germinating below $10 \mathrm{~cm}$ in the soil are unlikely to produce a hypocotyl long enough to reach the surface before their energy is expended (Milton and Hall, 1981). Isolated seeds germinating from these depths should not be a serious problem because seedling mortality increases with depth of germination (Milton and Hall, 1981).

\section{Towards a practical strategy for control and management of seed banks of invasive Australian Acacia species in South Africa}

\section{Which factors can be manipulated?}

Practical control measures are defined by limits imposed by features of the invaded environment and by biological traits of the invasive species. Successful control measures must remove adult plants and create as many barriers to invasion (or reestablishment) (sensu Richardson et al., 2000b) as possible. For example, the application of fire as part of integrated control is usually feasible in the fynbos and grassland biomes, but less so in dune systems and in riparian zones. Grazing is potentially useful in grasslands, but not in the fynbos. Floods are a crucial factor in the dynamics of invasive acacias in riparian zones and greatly complicate restoration efforts (Richardson et al., 2007). The scale, extent and configuration of invasive populations and the accessibility of the invaded terrain influence the feasibility of most control options (except biological control).

\section{Seed production}

Classical biological control (the introduction of specialist alien enemies to damage/destroy buds, flower and young pods) has effectively reduced the seed production of many Australian acacias in South Africa (Zimmermann et al., 2004). The devastating impact of the rust fungus, Uromycladium tepperianum, on A. saligna stands may also have stabilised seed numbers in seed banks (Morris, 1997, 1999; Morris et al., 1999). Biological control of the flower buds flowers and maturing pods with insects in the genera Trichilogaster (gall wasps), Dasineura (gall midges) and Melanterius (seed weevils), respectively, is greatly reducing the seed production of species such as A. longifolia, A. melanoxylon, A. cyclops (Dennill et al., 1999; Impson et al., 2004; Adair, 2005) and A. pycnantha (Hoffmann et al., 2002), and is probably stabilising seed banks of these species, although data to support this contention are lacking.

\section{Seed rain}

Apart from seeking ways to maximise the impacts of the indigenous organisms such as the alydids, the scope for intervention at this stage is very limited.

\section{Leaf litter}

Fire is the best available control option for killing seeds in the leaf litter. A moderate burn (see below), hot enough to consume the litter, should suffice for this purpose. In Australia, seed-sucking bugs of the genus Adrisa (family Cydnidae) are associated with the leaf litter under acacias (Gill, 1985; O'Dowd and Gill, 1986). These bugs could have potential for biological control but may not be sufficiently host specific (as far as we know this has not been investigated).

\section{Upper seed bank}

\section{Fire}

By either destroying or stimulating seeds to germinate (Milton and Hall, 1981; Esler and Boucher, 2004), fire is currently the most effective method for depleting Type A seed banks (but see below for discussion of the problems in implementation). In Acacia species from fire-prone ecosystems, such as A. mearnsii, A. longifolia, and $A$. saligna, water-impermeable dormancy is broken by exposure to a heat-pulse. A slow, hot fire depletes the seed bank more than a rapid fire, because besides killing seeds near the soil surface, it also stimulates germination of deeply buried seeds (Milton and Hall, 1981). Emerging seedlings can then be treated with a dicotyledon-specific herbicide such as Garlon (Campbell, 2000), or selectively grazed (Campbell et al., 1999; Campbell, 2000). The use of fire is also more suited to habitats where the target seed bank is shallow, such as in soils of the Table Mountain Group, where it would be followed-up by clearing (Esler and Boucher, 2004). Even though fire kills over $94 \%$ of the seed in A. cyclops seed banks (Holmes, 1989b), it is not appropriate for the control of Type B seed banks (Holmes et al., 1987a).

The use of fire for managing invasive trees and shrubs is controversial because unnaturally intense fires, resulting from the combustion of unnaturally large, alien plant biomass (Milton and Siegfried, 1981; Van Wilgen and Richardson, 1985), can destroy regenerative subterranean organs (Breytenbach, 1989) and indigenous seed banks (Holmes and Cowling, 1997) up to a depth of $0.15 \mathrm{~m}$ (Cilliers et al., 2004), destroy soil structure and sterilise soil for as long as 3 years (Campbell et al., 1999). Alien legume seeds, with the exception of 
A. cyclops, may be better at surviving high fire intensities than their indigenous counterparts (Jeffery et al., 1988). Euston-Brown et al. (2002) concluded that because of the negative effect of severe fires on the diversity and recovery of indigenous vegetation, such intense fires should be avoided whenever possible. Cilliers et al. (2004) called for an urgent review of the current practice of stacking and burning in fynbos.

The negative impact of fire can be managed to some extent by using fire behaviour models (Van Wilgen et al., 1985) to ensure that prescribed burns are done under conditions most likely to produce moderate intensities. Burning when the soil is moist is another option (Holmes, 2001a). It should be noted that although moderate fires reduce the potentially negative effects on native species, they are also less effective in killing acacia seeds. The options of "burn standing", "fell and burn", and "fell, remove and burn" should be considered (Van Wilgen et al., 1992; Holmes et al., 2000, 2008) to minimise the adverse effects of fire. Winter burning of live alien stands needs to be investigated further (Cilliers et al., 2004). Where isolated acacias occur in patches, these may be felled and the branches stacked over the area of the acacia seed bank some months before burning. When burnt, this results in "hot spots" that will kill or stimulate germination of the majority of the acacia seeds and localise the undesirable effects of the fire. The seedlings germinating in the "hot spots" can then be spot-sprayed with herbicides (Campbell, 2000). The problem with burning piles of felled slash is that usually the fuel bed is dense, resulting in residual burning of fuel at the soil surface. This damages the soil and indigenous propagules (Holmes and Foden, 2001; Euston-Brown et al., 2002; Cilliers et al., 2004), and the heat-scars can remain in the landscape for decades afterwards. It is always best to remove the utilisable fuel to minimise residual burning close to the soil surface. Where this is not feasible due to transport costs, it would be better to burn the stacks in winter (Cilliers et al., 2004) or to scatter the fuel widely. When the area next burns, some of the fuel will have decomposed and the fire should not be abnormally severe. The acacias will still germinate in the patches representing the localities of their seed banks and herbicide or hand pulling may be applied, depending on the density of the acacia recruitment. In dense acacia stands, felled slash is sometimes placed in piles, with gaps among them to facilitate access, and then the piles are burnt during the following wet season (winter in the south-western Cape) when the fires are easily controlled and damage to soils minimised (Cilliers et al., 2004). These are pragmatic approaches whose primary aims is to remove the dense acacia stands rather than to maximise recovery of indigenous vegetation. Under the circumstances, such actions may cause the least long-term damage to buried indigenous propagules (P.M. Holmes, personal commu- nication). Felling before burning is recommended for controlling non-sprouting species such as A. longifolia (Pieterse and Cairns, 1988), but not for coppicing species such as A. mearnsii (Pieterse and Boucher, 1997).

Considering the above problems, intense burns may be considered if there is the possibility of localised eradication of seed banks, otherwise moderate burns are preferable (Pieterse, 1997). Burning may also be inefficient. In grasslands, burning is typically patchy (Campbell et al., 1999), and in trials to control $A$. mearnsii seed banks, $99 \%$ and $74 \%$ of the seed remained dormant in the soil after a burn of brushwood and grass, respectively (Campbell et al., 1999).

\section{Felling}

Removal of vegetation and exposure of soil promotes the reduction of $A$. cyclops, i.e., Type B seed banks (Holmes, 1988, 1989b). Seed banks declined by over $80 \%$ during the first year after felling, both in the cleared area and under slash piles (Holmes, 1989b). These losses result from germination of the nondormant portion and rotting of the non-viable portion (Holmes, 1988). The stacks provide cover for rodent seed predators, and may exploit the shade intolerance of A. cyclops seedlings and promote damping-off (Milton, 1982). Felling alone will not reduce the seed banks of species that require a heat pulse to stimulate germination, i.e., Type A seed banks.

\section{Soil inversion}

Mechanically inverting the top $15-20 \mathrm{~cm}$ of the soil could greatly reduce seed survival and seedling emergence in Type B seed banks (Holmes and Moll, 1990), but is practical only in limited areas with deep sandy soils, for example in lowland fynbos.

\section{Solarisation}

This method involves attaining high soil temperatures $\left(40-70^{\circ} \mathrm{C}\right)$ near the soil surface by covering the soil with plastic sheeting. This can reduce seed viability and stimulate germination (Edgely, 1983). It is has been successfully tested for A. saligna in Israel (Cohen et al., 2004) and could be an option for Type A seed banks, although it has very limited application for controlling seed banks over large areas. It may be suitable for application in particularly sensitive habitats.

\section{Leaving stands to senesce}

The notion that an acacia thicket if left alone will senescence and eventually be replaced by indigenous vegetation is unrealistic. Fire exclusion is suitable for control in special situations of integrated land management but is generally not defensible for the control of Australian acacias and their seed banks (Milton, 1980a). Natural disturbances, such as storm damage, and the inevitable death of 30-40-year-old trees, regenerate 
patches continually, with gaps in the canopy soon being filled by acacia saplings (Milton and Hall, 1981).

\section{The role of micro-organisms}

Pathogens such as the rust fungus $U$. tepperianum reduce seed production and also deplete the seed bank by killing seedlings germinating from the transient seed bank (Morris, 1997, 1999). Legume seeds, such as those of soybean, have internal seed-borne pathogens such as Thielavia basicola and Pestalotia sp. (Nicolson and Sinclair, 1971). About 25 years ago, there was interest in the possibility of using such seed-borne micro-organisms to reduce seeds in weed seed banks (Kilpatrick and Bazzaz, 1979; Kremer, 1993). This approach was not pursued as it was deemed impractical (R.J. Kremer, in literature). The Australian acacias have not been checked for seed-borne pathogens (M.J. Morris, personal communication).

\section{Lower seed bank}

There seems to be little prospect for control of seeds in the lower seed bank. The best approach would be the management options above, to prevent seeds from moving upward to the upper seed bank where they can germinate and to keep seeds in the lower seed bank where they are effectively harmless.

\section{Overall management options}

\section{Containment}

Containment of seed banks is aimed at limiting the disturbance of the soil surface and soil profile in which the seed bank occurs, to minimise the creation of conditions for germination of seeds in the upper seed bank and also the upward movement of seeds from the lower seed bank. This includes sound soil conservation practices (e.g. preventing soil erosion) and cultural practices (e.g. oversowing with a cover crop - see below). Containment must be seen as an interim measure and not a long-term control option (see "Senescence" above). In the case of the weed $L$. salicaria, where management practices aimed at depleting the seed bank were investigated as a control option, it was concluded that even minor disturbances would make this approach ineffective (Welling and Becker, 1990).

\section{Rehabilitation}

Rehabilitation aims to establish any suitable vegetation cover as a cover crop, following the removal of alien plant cover (Campbell, 2000), and applies primar- ily to land outside conservation areas where any kind of non-invasive plant cover may be acceptable. The aim is to minimise disturbance of the soil surface to keep the seeds in the seed bank from germinating. Rehabilitation after alien plant control has been comprehensively covered for South Africa in a handbook compiled by Campbell (2000).

\section{Restoration}

"Restoration" generally strives to return a community to a state resembling its original condition, composition of function (Holmes and Richardson, 1999) and is usually applied in areas with conservation value. Feasible procedures vary from biome to biome. The CSIR (2000) produced guidelines for indigenous vegetation restoration following invasion by alien plants. For fynbos, restoration of invaded sites has been well studied by Patricia Holmes and co-workers (Holmes et al., 2000; Holmes, 2001b; Holmes and Foden, 2001). Community composition of the soil seed banks under dense infestations of Australian acacias in recently invaded fynbos was found to be similar to that of corresponding uninvaded fynbos at all sites, indicating that there is good potential for a return to speciesrich fynbos vegetation after removal of alien acacia species (Holmes and Cowling, 1997; Holmes et al., 2000; Holmes, 2002; Cilliers et al., 2004). Certain practices such as stacking and burning where there are dense infestations of alien acacias are not compatible with restoration aims (Cilliers et al., 2004). Where the indigenous vegetation has been eliminated, the potential for re-establishing it using donor seed banks or relic seed banks needs to be explored (Galatowitsch and Richardson, 2005).

\section{Conclusions}

Even from the limited information available on the seed bank dynamics of Australian acacias in South Africa, with most data for only three species, it is clear that efforts aimed specifically at eliminating or reducing already-formed seed banks are not feasible, certainly for application in major operations over very large areas in rough topography, such as the Working for Water Programme. Once seeds are on or in the soil, meaningful control options, apart from fire, are limited. Even the application of prescribed burning is very often problematical, given the very large amounts of fuel added by the invasive acacias. Preventing the accumulation of seed banks by limiting seed production is obviously the best approach. Although the large-scale, mechanical and chemical control programme of the Working for Water Programme must be having an impact on the seed 
production, and consequently on the future build-up of seed banks, this is, at best, leading to a slow attrition of the seed banks. Ongoing measures will be required over many decades to deal with new cohorts of seedlings. Biological control using seed-attacking insects is the most cost-effective, long-term option for limiting seed production (Kluge and Neser, 1987). Benefit:cost ratios of the biological control programmes of A. longifolia and $A$. pycnantha have been calculated to be 1465:1 and 4433:1, respectively (Van Wilgen et al., 2004). According to Holmes et al. (1987a), stopping seeding of $A$. saligna resulted in an $80 \%$ decline in its seed bank after $4-6$ years.

Approximately 24 seed-attacking biological control agents have been established on 22 alien woody invasives worldwide (Moran et al., 2004). The use of such agents, when integrated with a programme of clearing parent plants and seedlings, can translate into substantial savings for weed managers, even with modest levels of pre-dispersal seed mortality (Moran et al., 2004). Fewer seeds mean easier management through lower recruitment rates, fewer seedlings and reduced dispersal. The efficiency of seed dispersal of invasive plants is closely tied with seed numbers. Longdistance dispersal is crucial for rapid expansion and population growth of invasive plants (review in Trakhtenbrot et al., 2005). Reducing the amount of seed available for dispersal must therefore be effective in reducing invasiveness. Moran et al. (2004, 2005) illustrate the pivotal role seed-reducing insects have played in the successful South African biological control programmes against A. cyclops, A. pycnantha, and another woody legume, Sesbania punicea. Biological control agents that reduce seed production can also be key elements in rehabilitation and restoration (Moran et al., 2004). Seed-attacking insects should be the first line of defence in the successful control and management of woody invasive plants. Therefore, all species currently subject to biological control should be assessed and if necessary, additional biological control candidates should be introduced, to reduce seed production to as close to zero as possible.

In view of the limited options for dealing with the vast seed banks, and heeding the view of Moran et al. (2004), urgent consideration should be given to "biologically sterilising" all Australian acacias in South Africa that are not already under "complete" or "substantial" control (sensu Zimmermann et al., 2004), irrespective of their current status, by conducting research aimed at introducing at least one biological control agent per species to suppress seed production. This would substantially reduce the threat of large seed banks accumulating. Suppressing seed production could be particularly effective in preventing the build up of seed banks of emerging weeds (Kluge and Neser, 1987), such as $A$. baileyana and $A$. podalyriifolia. This would be in line with the latest trend where biological control is being applied to emerging weeds before they have become a serious problem (Olckers, 2004).

Weevils in the genus Melanterius should be the first option as biological control agents. There are 88 described species of Melanterius, almost all from Australia (Dennill and Donnelly, 1991), which feed and develop primarily on ripening pods and seeds of Acacia species (New, 1983). Five Melanterius species have been released in South Africa against seven different Acacia species and the closely related Paraserianthes lophantha (Dennill et al., 1999; Impson and Moran, 2004). Damage levels of the various wellestablished species on $A$. longifolia, $A$. melanoxylon, and $A$. cyclops can reach up to $90-100 \%$ (Dennill et al., 1999; Impson et al., 2004). These weevils have also proved relatively easy to collect, release and establish. With the considerable host-specificity testing already done with Melanterius species (Dennill and Donnelly, 1991; Dennill et al., 1999), together with the good safety record of seed-reducing and other insects utilised in biological control programmes (Cruttwell-McFadyen, 1998), it is likely that minimal or no additional testing will be required to obtain permission for the release of each new candidate species in South Africa. The project for each of the species will therefore require modest resources and consequently be highly cost-effective, even more so than the projects evaluated by Van Wilgen et al. (2004). However, any intended use of biological control of Australian acacias must take into consideration any conflict of interests (Hoffmann, 1991; Impson and Moran, 2004).

Fire, by either killing or stimulating seeds to germinate, is currently the best option for depleting Type A seed banks, at least in fire-adapted ecosystems. However, in situations where conservation of indigenous biological diversity is a central consideration, fire should be used judiciously or not at all. Fire should be integrated with other practices such as oversowing (Campbell, 2000). Fire is not essential for reducing Type B seed banks, but can be effective in some situations. All other control options such as shading and solarisation have very limited application in natural and semi-natural vegetation in South Africa, but could possibly be suitable for small, localised infestations or where highly sensitive habitats have been invaded. In conservation areas, a balance must be sought between maximising the reduction in acacia seed banks and minimising the damage to relictual, indigenous soilstored propagules.

The potential for managing seed banks to minimise germination is better than for reducing seeds in seed banks particularly in those ecosystems (e.g. forests) that are not fire adapted, where indigenous species recolonise in the absence of fire. Although the scheme in Table 1 is very general, it is clear that the control and management 
of any Australian acacia seed bank needs to be considered on a case by case basis with regard to species, age and density of stand, vegetation and the characteristics of the site. Control of the seed banks in recently established small populations should be prioritised over attempts to control well-established populations (Welling and Becker, 1990).

To further improve management and control of alien acacias, it would be wise to also have some estimate of the size of the seed banks when making the surveys of the infestations. This would indicate the importance of, and type of management for a site, and also predict the size of seedling populations likely to occur after a fire. Acacia seeds are relatively large, can be wet-sieved, dried and weighed to estimate numbers in density classes, e.g. zero, low, medium and high. Fifty soil cores are usually sufficient to get a reasonable estimate, although fewer may suffice if the aim is to provide rough estimates to guide management. Models could be prepared for different species, correlating the size of the seed bank with such factors as age and density of the infestation and the number and intensity of previous fires. Such information about the seed banks could be considered when deciding on management options. Alternatively, models with threshold levels, for example, based on the age to reach 1000 or 10000 seeds $\mathrm{m}^{-2}$ could be developed (P.M. Holmes, pers comm.). This information could also be used to prioritise invaded areas for control at a regional or national scale, so that "nascent foci" and recently invaded areas are given priority to prevent the formation of large seed banks. Old, dense stands could be left until last, as the alien seed banks are probably already large, and a few more years of seed bank build up would make little difference to management and control options. Results from population modelling studies also support the strategy of clearing sparse stands of $A$. cyclops before dense stands (Higgins et al., 2000).

More research is needed on Australian acacia seed banks in South Africa. The essential information required includes the size of the annual seed rain and the seed bank (number of seeds $\mathrm{m}^{-2}$ and percentage viability), type of dormancy (Type A or B), and survival and decay rates as done by Holmes (1989a) for $A$. cyclops and $A$. saligna. For the litter layer it may be useful to quantify the loss of seeds by rodents, birds, ants and alydids and also to identify any other indigenous seed predators. What could be important for management of the seed bank is to understand the processes that cause seeds in the seed bank to move between the upper and lower zones (e.g. the role of earthworms and moles). Such knowledge could possibly be used to promote practices which keep seeds in the lower seed bank, although the scope for manipulating these organisms over large areas appear to be limited. Also important is the movement of acacia seeds by animals horizontally over large distances. Managing dispersal agents could possibly play some role in an improved integrated management package for Australian acacias in South Africa (Buckley et al., 2006).

Because physical dormancy is common in seeds of legumes (Rolston, 1978) and consequently the nature of the resultant persistent seed banks are probably similar, the general conclusions discussed here for the control and management of Australian acacia seed banks probably apply to other potentially serious leguminous woody invaders such as Ulex europaeus (European gorse), Caesalpinnia decapetala (Mauritius or Mysore thorn), Gleditisia triacantha (honey locust), Mimosa pigra (giant sensitive plant), Robinia pseudoacacia (black locust), Cytisus scoparius (Scotch broom), Cytisus monspessulus (Montpellier broom), Senna species, Albizzia lebbeck (lebbeck tree), Albizzia procera (false lebbeck tree), Spartium junceum (Spanish broom) and Parkinsonia aculeata (green hair tree). Given the extent of invasions of these species, and the impracticality of most options for reducing soil-stored seed banks, sustainable management strategies must give priority to the reducing seed production through biological control. Supplementary options are required to achieve specific aims of management. As shown for Australian acacias in South Africa in this paper, the extent to which different options are practical and efficient depends of species traits and environmental conditions.

\section{Acknowledgements}

We thank P.M. Holmes (Environmental Resource Management Department, City of Cape Town), S.J. Milton (Centre for Invasion Biology, Department of Conservation Ecology and Entomology, Stellenbosch University), P.J. Pieterse (Department of Pasture Science, Stellenbosch University), and Alan Wood (Weed Pathology Unit, ARC-PPRI, Stellenbosch) for their constructive comments and suggestions. R. Adair (Victorian Department of Primary Industries, Australia), S. Neser and F.A.C. Impson (Plant Protection Research Institute, Pretoria and Stellenbosch, respectively) kindly provided information on the biological control agents. Thanks to F. Forcella (USDA-ARS Soils Lab, Morris, MT, USA) and J.H. Hoffmann (Zoology Department, University of Cape Town) for comments on the early drafts of the manuscript and to the librarians of the Department of Agriculture of KwaZulu-Natal at the Cedara Library for assistance. Preliminary ideas for this paper were presented at the 30th Weeds Biocontrol Workshop at Thaba Meetse in May 2002 where RLK was sponsored by the ARC, Plant Protection Research Institute. DMR acknowledges support from the DST-NRF Centre of Excellence for Invasion Biology. 


\section{References}

Adair, R., 2005. The biology of Dasineura dielsi Rübsaamen (Diptera: Cecidomyiidae) in relation to the biological control of Acacia cyclops (Mimosaceae) in South Africa. Aust. J. Entomol. 44, 446-456.

Baskin, C.C., Baskin, J.M., 1998. Seeds: Ecology, Biogeography and Evolution of Dormancy and Germination. Academic Press, San Diego, USA.

Bond, W., Slingsby, P.M., 1983. Seed dispersal by ants in shrublands of the Cape Province and its evolutionary implications. S. Afr. J. Sci. 79, 231-233.

Bond, W., Slingsby, P.M., 1984. Collapse of ant-plant mutualism: the Argentine ant (Iridomyrmex humilis) and myrmecochorous Proteaceae. Ecology 65, 1031-1037.

Breytenbach, G.J., 1989. Can we afford to slash and burn hakea in fynbos ecosystems? S. Afr. For. J. 151, 6-16.

Buckley, Y.M., Anderson, S., Catterall, C.P., Corlett, R.T., Engel, T., Gosper, C.R., Nathan, R., Richardson, D.M., Setter, M., Spiegel, O., Vivian-Smith, G., Voigt, F.A., Weir, J.E.S., Westcott, D.A., 2006. Management of plant invasions mediated by frugivore interactions. J. Appl. Ecol. 43, 848-857.

Campbell, P.L., 2000. Rehabilitation recommendations after alien plant control. In: Plant Protection Research Handbook No. 11. Agricultural Research Council, Pretoria, South Africa.

Campbell, P.L., Naude, D., Kluge, R.L., 1999. Development of integrated control strategies for wattle. II. Control of unwanted wattle. S. Afr. J. Plant Soil 16, 31-37.

Cilliers, C.D., Eesler, K.J., Boucher, C., 2004. Effects of alien plant management and fire on soil seed banks and regeneration in the Cape Peninsula National Park, South Africa. S. Afr. J. Bot. 70, 705-712.

Cohen, O., Bar (Kutiel), P., Katan, J., Riov, J., Gamliel, A., 2004. Soil solarization as a method for reducing viability of invasive woody seed bank - The case of Acacia saligna. In: Arianoutsou, M., Papanastasis, V.P. (Eds.), Proceedings 10th MEDECOS, 25 April-1 May 2004. Millpress, Rotterdam, The Netherlands.

Cruttwell-Mcfadyen, R.E., 1998. Biological control of weeds. Ann. Rev. Entomol. 43, 369-393.

CSIR, 2000. Guidelines for indigenous vegetation restoration following invasion by alien plants. ERV-S-C 2000-144. CSIR, Stellenbosch, South Africa.

Davidson, D.W., Morton, S.R., 1984. Dispersal adaptations of some Acacia species in the Australian arid zone. Ecology 65, 1038-1051.

Dean, S.J., Holmes, P.M., Weiss, P.W., 1986. Seed biology of invasive alien plants in South Africa and Namibia. In: Macdonald, I.A.W., Kruger, F.J., Ferrar, A.A. (Eds.), The Ecology and Management of Biological Invasions in Southern Africa. Oxford University Press, Cape Town, South Africa, pp. 157-170.

De Neergaard, A., Saarnak, C., Hill, T., Khanyile, M., Berzosaa, A.M., Birch-Thomsen, T., 2005. Australian wattle species in the Drakensberg region of South Africa - An invasive tree or a natural resource? Agric. Syst. 85, 216-233.

Dennill, G.B., Donnelly, D., 1991. Biological control of Acacia longifolia and related weed species. Agric. Ecosys. Environ. 37, 115-136.
Dennill, G.B., Donnelly, D., Stewart, K., Impson, F.A.C., 1999. Insect agents used for the biological control of Australian Acacia species and Paraserianthes lophantha (Wiid.) Nielsen (Fabaceae) in South Africa. Afr. Entomol. Mem. 1, 45-54.

Donnelly, D., Stewart, K., 1990. An indigenous tortricid moth on the seeds of an alien weed Acacia cyclops in South Africa. J. Entomol. Soc. S. Afr. 53, 202-203.

Duckworth, A., Richardson, D., 1988. Notes on the diet of helmeted guineafowl (203) in the Jonkershoek Valley, Stellenbosch. Promerops 186, 11.

Edgely, G.H., 1983. Weed seed and seedling reduction by soil solarisation with transparent polythene sheeting. Weed Sci. 31, 404-409.

Esler, K.J., Boucher, C., 2004. The potential impact of alien woody plant invasions and their control on alien seed banks in the Western Cape, South Africa. In: Arianoutsou, M., Papanastasis, V.P. (Eds.), Proceedings of the 10th MEDECOS, 25 April-1 May 2004. Millpress, Rotterdam, The Netherlands.

Euston-Brown, D.I.W., Botha, S., Bond, W.J., 2002. The influence of fire severity on post fire vegetation recovery on the Cape Peninsula. Unpublished Final Report. Department of Water Affairs and Forestry, Working for Water Programme, Cape Town, South Africa.

Foxcroft, L.C., Rouget, M., Richardson, D.M., 2007. Risk assessment of riparian plant invasions into protected areas. Conserv. Biol. 21, 412-421.

Fraser, M.W., 1990. Foods of Redwinged Starlings and the potential for avian dispersal of Acacia cyclops at the Cape of Good Hope Nature Reserve. S. Afr. J. Ecol. 1, 73-76.

French, K., Major, R.E., 2001. Effect of an exotic Acacia (Fabaceae) on ant assemblages in South African fynbos. Aust. Ecol. 26, 303-310.

Galatowitsch, S.M., Richardson, D.M., 2005. Riparian scrub recovery after clearing of invasive alien trees in headwater streams of the Western Cape, South Africa. Biol. Conserv. 122, 509-521.

Geldenhuys, C.L., 1986. Costs and benefits of Australian blackwood Acacia melanoxylon in South African forestry. In: Macdonald, I.A.W., Kruger, F.J., Ferrar, A.A. (Eds.), The Ecology and Management of Biological Invasions in Southern Africa. Oxford University Press, Cape Town, South Africa, pp. 275-283.

Gill, A.M., 1985. Acacia cyclops G. Don (Leguminosae: Mimosaceae) in Australia: distribution and dispersal. J. R. Soc. W. Aust. 67, 59-65.

Glyphis, J.P., Milton, S.J., Siegfried, W.R., 1981. Dispersal of Acacia cyclops by birds. Oecologia 48, 138-141.

Harper, J., 1977. Population Dynamics of Plants. Academic Press, London, UK.

Hendrix, S.D., Trapp, E.J., 1992. Population demography of Pastina sativa (Apiaceae): effect of seed mass on emergence, survival and recruitment. Am. J. Bot. 79, 365-375.

Higgins, S.I., Richardson, D.M., Cowling, R.M., 2000. Using a dynamic landscape model for planning the management of alien plant invasions. Ecol. Appl. 10, 1833-1848.

Hoffmann, J.H., 1991. Introduction. Special Issue, Biological control of weeds in South Africa. Agric. Ecosyst. Environ. $37,1-3$. 
Hoffmann, J.H., Impson, F.A.C., Moram, V.C., Donnelly, D., 2002. Biological control of invasive golden wattle (Acacia pycnantha) by a gall wasp, Trichilogaster sp. (Hymenoptera: Pteromalidae) in South Africa. Biol. Cont. 25, 64-73.

Holmes, P.M., 1988. Implications of alien Acacia seed bank viability and germination for clearing. S. Afr. J. Bot. 54, 281-284.

Holmes, P.M., 1989a. Decay rates for buried Acacia seed populations of different density. S. Afr. J. Bot. 55, 299-303.

Holmes, P.M., 1989b. Effects of different clearing treatments on the seed-bank dynamics of an invasive Australian shrub, Acacia cyclops, in the South-western Cape, South Africa. For. Ecol. Manage. 28, 33-46.

Holmes, P.M., 1990a. Dispersal and predation of alien Acacia seeds: effects of season and invading stand density. S. Afr. J. Bot. 56, 428-434.

Holmes, P.M., 1990b. Dispersal and predation in alien Acacia. Oecologia 83, 288-290.

Holmes, P.M., 1990c. Vertical movement of soil-stored seed at a sand plain fynbos site. S. Afr. J. Ecol. 1, 8-11.

Holmes, P.M., 2001a. A comparison of the impact of winter versus summer burning of slashed alien-invaded fynbos areas in the Western Cape. S. Afr. For. J. 192, 41-50.

Holmes, P.M., 2001b. Shrubland restoration following woody alien invasion and mining: effects of topsoil depth, seed source, and fertilizer addition. Rest. Ecol. 9, 71-84.

Holmes, P.M., 2002. Depth distribution and composition of seed banks in alien-invaded and invaded and uninvaded fynbos vegetation. Aust. Ecol. 27, 110-120.

Holmes, P.M., Cowling, R.M., 1997. Diversity, composition and guild structure relationships between soil-stored seed banks and mature vegetation in alien plant-invaded South African fynbos shrublands. Plant Ecol. 133, 107-122.

Holmes, P.M., Foden, W., 2001. The effectiveness of post-fire soil disturbance in restoring fynbos after alien clearance. S. Afr. J. Bot. 67, 533-539.

Holmes, P.M., Moll, E.J., 1990. Effect of depth and duration of burial on alien Acacia saligna and Acacia cyclops seeds. S. Afr. J. Ecol. 1, 12-17.

Holmes, P.M., Newton, R.J., 2004. Patterns of seed persistence in South African fynbos. Plant Ecol. 172, 143-158.

Holmes, P.M., Rebelo, A.G., 1988. The occurrence of seedfeeding Zulubius acaciaphagus (Hemiptera, Alydidae) and its effects on seed germination and seed banks in South Africa. S. Afr. J. Bot. 54, 319-324.

Holmes, P.M., Richardson, D.M., 1999. Protocols for restoration based on recruitment dynamic, community structure and ecosystem function: perspectives for South African fynbos. Rest. Ecol. 7, 215-230.

Holmes, P.M., Macdonald, I.A.W., Juritz, J., 1987a. Effect of clearing treatment on seed banks of alien invasive shrubs Acacia saligna and Acacia cyclops in the southern and south western Cape, South Africa. J. Appl. Ecol. 24, 1045-1051.

Holmes, P.M., Dennill, G.B., Moll, E.J., 1987b. Effects of feeding by native alydid insects on the seed viability of an alien invasive weed, Acacia cyclops. S. Afr. J. Sci. 83, 580-581.

Holmes, P.M., Richardson, D.M., Van Wilgen, B.W., Gelderblom, C., 2000. Recovery of South African fynbos vegetation following alien woody plant clearing and fire: implications for restoration. Aust. Ecol. 25, 631-639.
Holmes, P.M., Richardson, D.M., Esler, K.J., Witkowski, E.T.F., Fourie, S., 2005. A decision-making framework for restoring riparian zones degraded by invasive alien plants in South Africa. S. Afr. J. Sci. 101, 553-564.

Holmes, P.M., Esler, K.J., Richardson, D.M., Witkowski, E.T.F., 2008. Guidelines for improved management of riparian zones invaded by alien plants in South Africa. S. Afr. J. Bot. 74, in press, doi:10.1016/j.sajb.2008.01.182.

Impson, F.A.C., Moran, V.C., 2004. Thirty years of exploration for and selection of Melanterius weevils for biological control of invasive Australian acacias in South Africa: should we have done anything differently? In: Abstracts for Proceedings of the XIth International Symposium on the Biological Control of Weeds, Canberra, Australia, p. 115.

Impson, F.A.C., Moran, V.C., Hoffmann, J.H., 2004. Biological control of an alien tree, Acacia cyclops, in South Africa: impact and dispersal of a seed-feeding weevil, Melanterius servulus. Biol. Cont. 29, 375-381.

Jeffery, D.J., Holmes, P.M., Rebelo, A.G., 1988. Effects of dry heat on seed germination in selected indigenous and alien legume species in South Africa. S. Afr. J. Bot. 54, $28-34$.

Kilpatrick, B.L., Bazzaz, F.A., 1979. Influence of certain fungi on seed germination and seedling survival of four colonizing annuals. J. Appl. Ecol. 16, 515-527.

Kluge, R.L., Neser, S., 1987. The importance of seed-attacking insects in the biological control of invasive alien plants. In: Macdonald, I.A.W., Kruger, F.J., Ferrar, A.A. (Eds.), The Ecology and Management of Biological Invasions in Southern Africa. Oxford University Press, Cape Town, South Africa, pp. 285-294.

Knight, R.S., Macdonald, I.A.W., 1991. Acacias and korhaans: an artificially assembles seed dispersal system. S. Afr. J. Bot. 57, 220-225.

Kremer, R.J., 1993. Management of weed seed banks with microorganisms. Appl. Ecol. 3, 42-52.

Kruger, F.J., 1979. Conservation: South African heathlands. In: Specht, R.L. (Ed.), Heathlands and Related Shrublands of the World. B. Analytical Studies. Elsevier, Amsterdam, The Netherlands, pp. 231-234.

Le Maitre, D.C., Van Wilgen, B.W., Chapman, R.A., McKelly, D.H., 1996. Invasive plants and water resources in the Western Cape Province, South Africa: modelling the consequences of lack of management. J. Appl. Ecol. 33, $161-172$

Lubke, R.A., 1985. Erosion of the beach at St Francis Bay, Eastern Cape, South Africa. Biol. Conserv. 32, 99-127.

Manning, J.C., Van Staden, J., 1987. The role of the lens in seed imbibition and seedling vigour of Sesbania punicea (Cav.) Benth. (Leguminosae: Papilionidae). Ann. Bot. 59, 705-713.

Marais, C., Van Wilgen, B.W., Stevens, D., 2004. The clearing of invasive alien plants in South Africa: a preliminary assessment of costs and progress. S. Afr. J. Sci. 100, 97-103.

Maslin, B.R., 2001. Wattle. Acacias of Australia. Australian Biological Resources Study, Canberra, Australia.

Midgley, J.J., Bond, W.J., 1995. Relative attractiveness of seeds of myrmecochorous Australian and South African plants to ants, and the chemical basis of this attraction. S. Afr. J. Bot. 61, 230-232. 
Milton, S.J., 1980a. Studies of Australian acacias in the south western Cape. M.Sc. Thesis. University of Cape Town, Cape Town, South Africa.

Milton, S.J., 1980b. Australian acacias in the south-western Cape: pre-adaptation predation and success. In: Cairns, A.L.P., Neser, S. (Eds.), Proceedings of the 3rd National Weed Conference of Southern Africa, Stellenbosch, pp. 69-78.

Milton, S.J., 1982. Effects of shading on nursery-grown acacias. J. S. Afr. Bot. 48, 245-272.

Milton, S.J., Hall, A.V., 1981. Reproductive biology of Australian acacias in the south-western Cape province, South Africa. Trans. R. Soc. S. Afr. 44, 465-485.

Milton, S.J., Siegfried, W.R., 1981. Above-ground biomass of Australian acacias in the southern Cape, South Africa. J. S. Afr. Bot. 47, 701-716.

Moran, V.C., Hoffmann, J.H., Olckers, T., 2004. Politics and ecology in the management of alien invasive woody trees: the pivotal role of biological control agents that diminish seed production. In: Proceedings of the XIth International Symposium on Biological Control of Weeds, Canberra, Australia.

Moran, V.C., Hoffmann, J.H., Zimmermann, H.G., 2005. Biological control of invasive alien plants in South Africa: necessity, circumspection, and success. Front. Ecol. Environ. 3, 71-77.

Morris, M.J., 1997. Impact of the gall-forming rust fungus, Uromycladium tepperianum on the invasive tree Acacia saligna in South Africa. Biol. Cont. 10, 75-82.

Morris, M.J., 1999. The contribution of the rust fungus Uromycladium tepperianum (Sacc.) McAlp. to the biological control of Acacia saligna (Labill.) Wendl. (Fabaceae) in South Africa. Afr. Entomol. Mem. 1, 125-128.

Morris, M.J., Wood, A.R., Den Breeyen, A., 1999. Plant pathogens and biological control of weeds in South Africa: a review of projects and progress during the last decade. Afr. Entomol. Mem. 1, 129-138.

Nel, J.L., Richardson, D.M., Rouget, M., Mgidi, T., Mdzeke, N., Le Maitre, D.C., Van Wilgen, B.W., Schonegevel, L., Henderson, L., Neser, S., 2004. A proposed classification of invasive alien plant species in South Africa: towards prioritising species and areas for management action. S. Afr. J. Sci. 100, 53-64.

New, T.R., 1983. Seed predation of some Australian acacias by weevils (Coleoptera: Curculionidae). Aust. J. Zool. 31, 345-352.

Nicolson, J.F., Sinclair, J.B., 1971. Thielavia basicola and Pestalotia sp. internally seedborne soybean pathogens. Plant Dis. Rep. 55, 911-912.

O’Dowd, D.J., Gill, A.M., 1986. Seed dispersal syndromes of Australian Acacia. In: Murray, D. (Ed.), Seed Dispersal. Academic Press, New York, USA, pp. 87-121.

Olckers, T., 2004. Targeting emerging weeds for biological control in South Africa: the benefits of halting the spread of alien plants at an early stage of their invasion. S. Afr. J. Sci. $100,64-68$.

Paynter, Q., Csurhes, S.M., Heard, T.A., Ireson, J., Julien, M.H., Lloyd, J., Lonsdale, W.M., Palmer, W.A., Sheppard, A.W., Van Klinken, R.D., 2003. Worth the risk? Introduction of legumes can cause more harm than good: an Australian perspective. Aust. Syst. Bot. 16, 81-88.
Pieterse, P.J., 1987. Acacia longifolia and its control: to burn or not to burn? Veld \& Flora 73, 67-68.

Pieterse, P.J., 1997. Biological studies on woody leguminous invaders with special reference to Acacia mearnsii, Acacia melanoxylon and Paraserianthes lophantha. Ph.D. Thesis. Stellenbosch University, Stellenbosch.

Pieterse, P.J., 1998. Seed damage by indigenous Alydidae (Heteroptera) on the exotic Acacia implexa (Fabaceae). Afr. Plant Prot. 4, 11-13.

Pieterse, P.J., Boucher, C., 1997. Is burning a standing population of invasive legumes a viable control method? Effects of a wildfire on an Acacia mearnsii population. S. Afr. For. J. 180, 15-21.

Pieterse, P.J., Cairns, A.L.P., 1986. The effect of fire on an Acacia longifolia seed bank in the south-western Cape. S. Afr. J. Bot. 52, 233-235.

Pieterse, P.J., Cairns, A.L.P., 1988. The population dynamics of the weed Acacia longifolia (Fabaceae) in the absence and presence of fire. S. Afr. For. J. 145, 25-27.

Richardson, D.M., Van Wilgen, B.W., 2004. Invasive alien plants in South Africa: how well do we understand the ecological impacts? S. Afr. J. Sci. 100, 45-52.

Richardson, D.M., Macdonald, I.A.W., Forsyth, G.G., 1989. Reductions in plant species richness under stands of alien trees and shrubs in the fynbos biome. S. Afr. For. J. 149, $1-8$.

Richardson, D.M., Macdonald, I.A.W., Holmes, P.M., Cowling, R.M., 1992. Plant and animal invasions. In: Cowling, R.M. (Ed.), The Ecology of Fynbos: Nutrients, Fire and Diversity. Oxford University Press, Cape Town, South Africa, pp. 271-308.

Richardson, D.M., Van Wilgen, B.W., Higgins, S.I., TrinderSmith, T.H., Cowling, R.M., McKelly, D.H., 1996. Current and future threats to biodiversity on the Cape Peninsula. Biodiv. Conserv. 5, 607-647.

Richardson, D.M., Macdonald, I.A.W., Hoffmann, J.H., Henderson, L., 1997. Alien plant invasions. In: Cowling, R.M., Richardson, D.M., Pierce, S.M. (Eds.), Vegetation of Southern Africa. Cambridge University Press, Cambridge, UK, pp. 535-570.

Richardson, D.M., Allsopp, N., D’Antonio, C.M., Milton, S.J., Rejmánek, M., 2000a. Plant invasions: the role of mutualisms. Biol. Rev. 75, 65-93.

Richardson, D.M., Pyšek, P., Rejmánek, M., Barbour, M.G., Panetta, F.D., West, C.J., 2000b. Naturalization and invasion of alien plants: concepts and definitions. Diversity Distrib. 6, 93-107.

Richardson, D.M., Bond, W.J., Dean, W.R.J., Higgins, S.I., Midgley, G.F., Milton, S.J., Powrie, L., Rutherford, M.C., Samways, M.J., Schulze, R.E., 2000c. Invasive alien organisms and global change: a South African perspective. In: Mooney, H.A., Hobbs, R.J. (Eds.), Invasive Species in a Changing World. Island Press, Washington, DC, USA, pp. 303-349.

Richardson, D.M., Cambray, J.A., Chapman, R.A., Dean, W.R.J., Griffiths, C.L., Le Maitre, D.C., Newton, D.J., Winstanley, T.J., 2003. Vectors and pathways of biological invasions in South Africa - past, future and present. In: Ruiz, G., Carlton, J. (Eds.), Invasive Species: Vectors and Management Strategies. Island Press, Washington, DC, USA, pp. 292-349. 
Richardson, D.M., Binggeli, P., Schroth, G., 2004. Invasive agroforestry trees: problems and solutions. In: Schroth, G., de Fonseca, G.A.B., Harvey, C.A., Gascon, C., Vasconcelos, H., Izac, A.-M.N. (Eds.), Agroforestry and Biodiversity Conservation in Tropical Landscapes. Island Press, Washington, DC, pp. 371-396.

Richardson, D.M., Holmes, P.M., Esler, K.J., Galatowitsch, S.M., Stromberg, J.C., Kirkman, S.P., Pyšek, P., Hobbs, R.J., 2007. Riparian zones-degradation, alien plant invasions and restoration prospects. Diversity Distrib. 13, 126-139.

Roberts, H.A., Feast, P.M., 1972. Fate of seeds of some annual weeds in different depths of cultivated and undisturbed soil. Weed Res. 12, 316-324.

Rolston, M.P., 1978. Water impermeable seed dormancy. Bot. Rev. 44, 365-396.

Rouget, M., Richardson, D.M., 2003. Inferring process from pattern in alien plant invasions: a semimechanistic model incorporating propagule pressure and environmental factors. Am. Nat. 162, 713-724.

Rouget, M., Richardson, D.M., Cowling, R.M., Lloyd, J.W., Lombard, A.T., 2003. Current patterns of habitat transformation and future threats to biodiversity in the Cape Floristic Region, South Africa. Biol. Conserv. 112, 63-85.

Rouget, M., Richardson, D.M., Nel, J.L., Le Maitre, D.C., Egoh, B., Mgidi, T., 2004. Mapping the potential spread of major plant invaders in South Africa using climatic suitability. Diversity Distrib. 10, 475-484.

Stirton, C.H. (Ed.), 1978. Plant Invaders: Beautiful but Dangerous. Department of Nature and Environmental Conservation, Provincial Administration, Cape Town, South Africa.

Stock, W.D., Wienand, K.T., Baker, A.C., 1995. Impacts of invading $\mathrm{N}_{2}$-fixing acacia species on patterns of nutrient cycling in two Cape ecosystems: evidence from soil incubation studies and $\mathrm{N}$ natural abundance values. Oecologia 101, 375-382.

Thompson, K., Grime, J.P., 1979. Seasonal variation in seed banks of herbaceous species in ten contrasting habitats. J. Ecol. 67, 893-921.

Thompson, K., Ceriani, R.M., Bakker, J.P., Bakker, R.M., 2003. Are seed dormancy and persistence in soil related? Seed Sci. Res. 13, 97-100.

Török, I.H., 1999. European bee-eaters and the occupants of their burrows - friends or enemies? Bird Numbers 8. Available online at: 〈http://web.uct.ac.za/depts/stats/adu/ bn8_1_06.htm $\rangle$ (accessed 27.02.2008).

Trakhtenbrot, A., Nathan, R., Perry, G., Richardson, D.M., 2005. The importance of long-distance dispersal in biodiversity conservation. Diversity Distrib. 11, 173-181.
Underhill, L.G., Hofmeyr, J.H., 2007. Barn Swallows Hirundo rustica disperse seeds of Rooikrans Acacia cyclops, an invasive alien plant in the Fynbos Biome. Ibis 149, 468-471.

Van Wilgen, B.W., Richardson, D.M., 1985. The effects of alien shrub invasions on vegetation structure and fire behaviour in South African fynbos shrublands: a simulation study. J. Appl. Ecol. 22, 955-966.

Van Wilgen, B.W., Le Maitre, D.C., Kruger, F.J., 1985. Fire behaviour in South African fynbos (macchia vegetation) and predictions from Rothermel's fire model. J. Appl. Ecol. 22, 207-216.

Van Wilgen, B.W., Bond, W.J., Richardson, D.M., 1992. Ecosystem management. In: Cowling, R.M. (Ed.), The Ecology of Fynbos: Nutrients, Fire and Diversity. Oxford University Press, Cape Town, South Africa, pp. $345-371$.

Van Wilgen, B.W., Richardson, D.M., Le Maitre, D.C., Marais, C., Magadlela, D., 2001. The economic consequences of alien plant invasions: examples of the impacts and approaches to sustainable management in South Africa. Environ. Dev. Sustain. 3, 145-168.

Van Wilgen, B.W., De Witt, M.P., Anderson, H.J., Le Maitre, D.C., Kotze, I.M., Ndala, S., Brown, B., Rapholo, M.B., 2004. Costs and benefits of biological control of invasive alien plants: case studies from South Africa. S. Afr. J. Sci. 100, 113-122.

Welling, C.H., Becker, R.L., 1990. Seed bank dynamics of Lythrum salicaria L.: implications for control of this species in North America. Aquat. Bot. 8, 303-309.

Wilson, J.R.U., Richardson, D.M., Rouget, M., Procheș, Ş., Amis, M.A., Henderson, L., Thuiller, W., 2007. Residence time and potential range: crucial considerations in modelling plant invasions. Diversity Distrib 13, 11-22.

Witkowski, E.T.F., 1991. Growth and competition between seedlings of Protea repens (L) L. and the alien invasive Acacia saligna (Labill.) Wendl. in relation to nutrient availability. Funct. Ecol. 5, 101-110.

Yelenik, S., Stock, W.D., Richardson, D.M., 2004. Ecosystemlevel impacts of invasive alien nitrogen fixing plants. Ecosystem and community-level impacts of invasive alien Acacia saligna in the fynbos vegetation of South Africa. Rest. Ecol. 12, 44-51.

Yelenik, S., Stock, W.D., Richardson, D.M., 2007. Functional group identity does not predict invader impacts: differential effects of $\mathrm{N}$-fixing exotic plants on ecosystem function. Biol. Invasions 9, 117-125.

Zimmermann, H.G., Moran, V.C., Hoffmann, J.H., 2004. Biological control in the management of invasive alien plants in South Africa, and the role of the Working for Water programme. S. Afr. J. Sci. 100, 34-40. 